\title{
RELEVANT HISTORY
}

\section{A CHRISTIAN VIEW ON THE TASK OF THE HISTORIAN PROVIDES AN ANSWER TO THE PRESENT CRISIS IN HISTORICAL STUDY}

Historians of today probably have to face more criticism of and attacks on their discipline than any of their predecessors. Twentieth century society and its political and intellectual leaders- including scholars in fields other than history - are seriously questioning the value of history, and doubt whether history is able to make a contribution towards the solution of contemporary problems. Many people have looked to historians for an authoritative answer on questions concerning the future of Western Civilization and the possibility of averting further catastrophic world conflicts, only to be disappointed. People of our age expect science to be of direct practical value, and students of today, who are often disillusioned with the society in which they are living and with its inability to achieve peace and prosperity for all people, want to study only subjects which can make an evident contribution toward the solution of contemporary problems and the creation of a better world. Also those students who are quite satisfied to prepare themselves for a career within the present establishment often regard history as an unnecessary subject; they prefer to study natural sciences, economics or new-fangled social sciences such as criminology or polemology. The study of the social sciences is flourishing in many schools and universities today, especially at the expence of history as a traditional element of the curriculum. The number of people who are studying history in the higher forms of the secondary school and at university level is steadily declining, not only in South Africa, but in most other countries as well. 1)

Why do so many people regard history today as unimportant for practical life? Three of the main reasons seem to be the following: 
(a) that the practical value of history is not as apparent as that of most other disciplines,

(b) that the general attitude of people of today obscures a true understanding of history, and

(c) that historians fail to write history which is really directed at present day problems.

This article deals with the historian and his share in the responsibility for the crisis in historical study. The historian's failure to write history that is relevant for today could be attributed to

(a) lack of proper methods, or of the skill to use them for writing history which will have practical value, and/or (b) an erroneous view or lack of reflection on the aims the historian has to achieve with his work. Many historians are designing and using new methods of historical study in an attempt to find a solution for the present crisis. ${ }^{2}$ ) It is my belief, however, that new methods will not be sufficient to provide a solution for the crisis in history. What is needed in the first place is a clear and correct perspective on the task of the historian, because only when the aims of historical study are seen in true perspective is it possible to find suitable methods to achieve these aims. In the first section of this article I shall try to point out briefly that the lack of a correct perspective on the task of the historian contributes largely to the present crisis in historical study, and thereafter I shall discuss the aims that should be achieved in historical study in order to make history relevant to present society and its problems.

SOME VIEWS ON THE AIMS OF HISTORICAL STUDY WHICH HAVE BEEN PREVALENT UNTIL TODAY. The view that was formed in the Classical Age on the aims of historical study remained the prevailing one for centuries and contributed to a large extent to the crisis in historical study in the twentieth century.

Herodotus and Thucydides, who lived in the fifth century $B C$ and are generally regarded as two of the first 
historians of importance, considered it their main task to provide useful information. With his work on the Peloponnesian War Thucydides wanted to be of use to posterity, who, as he believed, would have to cope with similar problems. He carefully described the symptoms of a plague-epidemic in order to enable people to recognize such an epidemic, should it break out again. ${ }^{3}$ ) The Greeks believed that, in the same way that the four seasons returned every year and everybody went through the same cycle of being born, growing up, growing old and dying, all events that had happened would happen again some time. Both Herodotus and Thycydides believed that human nature always remained the same; people always act in the same way and the same actions always have the same results. ${ }^{4}$ )

History was therefore considered to be subject to the cyclical course of nature and to consist of loose collections of events which recurred from cycle to cycle. Greek philosophers regarded the knowledge gained from nature, from fixed, permanent things, to be reliable and of general validity. Knowledge obtained from the innumerable, ever-changing events of history, however, was regarded as unreliable, because it could not be tested, and was not of general validity, being merely applicable to particular events. History was not regarded as a science, such as mathematics or physics, but as an art, such as poetry or rhetoric. Some historians (e g Polybius) considered accuracy to be of primary importance in historical writing, but others, and with them the general public, valued artistic expression, the convincing reasoning and the entertainment and moral education of the reader higher, and accuracy was often sacrificed for the sake of achieving these aims. History was believed to be important for the moral education of people because it could point out the way towards a good life by giving examples of lives and deeds that were worthy of being followed and by showing what kind of actions brought disaster on people and should be avoided. It was possible to learn from the experiences of others through the study of history. Especially to people who were preparing themselves for a public career -for future statesmen - the 
study of history, of the deeds of great people of the past and of the consequences of these actions was considered a necessity. ${ }^{5}$ )

This examplar view of history ${ }^{9}$ remained prevalent until the eighteenth Century. The spread of Christianity introduced a new perspective on history with the idea of the unity and continuity of world history; this was a linear view instead of the Classical cyclical view of history. The consequences of the Christian view of history for historical writing were, however, not fully realized. Throughout the Middle Ages historical works consisted mainly of chronicles, in which events were related one after another without pointing out the relations between them, and of biographies of saints which served as examples of virtuous Christian living for the edification of the people. ${ }^{7}$ )

The historians of the Renaissance copied various aspects of Classical historiography. They upheld the exemplar view of history, and the sixteenth century philosopher Jean Bodin wanted to classify the examples of history in categories of good, base, useful and worthless. In this way he wanted to make history more systematised and scientific, but his work could serve as the beginning of a systematic study of morals, not a scientific study of history. ${ }^{8}$ ) During the eighteenth century the idea of progress was prevalent, and histories were written with the aim of showing man's continual progress through the ages. Suitable facts from different periods and places were selected and put together in the conjectural histories that were written at that time; the idea of progress was a presupposition in these works and was not proved by them. Although historiography attained a much higher level than ever before, it was still generally believed that "the advantages found in history seem to be of three kinds, as it amuses the fancy, as it improves the understanding, and as it strengthens virtue". ${ }^{9}$ ) There was no perspective yet on the real nature of history.

During the nineteenth century, however, history was seen in a new light; this century was indeed the most historically minded of all centuries. For those who lived 
in the first decades of the century it seemed that the attempts which were made during the French Revolution to radically change society according to the principles of pure reason (as they were laid down by eighteenth century philosophers) had failed totally. The failure of the French Revolution showed them that things which had come about and had developed and established themselves in the course of centuries could not be wiped away in a few days or a few years. In the age of the Romantics the idea was conceived that there was a hidden law contained in history, a secret wisdom of history, according to which institutions and the whole structure of society gradually developed in such a way that it took the form which was the best possible for its particular age. Therefore, not abstract reasoning should be used to find out how things ought to be, but knowledge of how existing things had originated and developed. History should be studied, especially by leaders of society, in order to reveal the traditions according to which they should act, for it was believed that one could not do better than to continue in the tracks of one's ancestors. In the view of the Romantics history was no longer of primary importance because of the useful examples and moral lessons it provided, but because it showed the lines of development that stretched into their own time. History was no more seen as a loose collection of events, but as an organic whole. It was even believed that a nation was an organic entity with a national soul, and that the soul of a people could best be understood by studying its origins in Medieval times. The Romantics, in their escape from their own era which seemed to them colourless and dreary, were attracted by the strange, exotic cultures of past ages. They realized that every age had its own atmosphere which could only be sensed through the emotions and the imagination. ${ }^{10}$ )

The view of history of the Romantics was closely affiliated with the traditional Christian view of history. Under the influence of the Romantics Christians of the early nineteenth century believed that everything which had developed in history had done so under the special care of God and that the wisdom of history which made all 
things develop in the best possible way should actually be seen as the working of God in history. History, and especially national history, was believed to show guiding principles for life. The principles derived from both the Bible and from history, which together were referred to as Christian-historical principles, were juxtaposed against those of rationalism and of the French Revolution by the Dutch Calvinist Groen van Prinksterer and his followers. ${ }^{11}$ )

The view of history of the Romantics was, however, not only accomodated in Christian life- and world-view, but also in rationalist philosophy. According to Georg Wilhelm Hegel the wisdom of history should not be identified with the working of God in history, but with the cunning of reason; historical development is therefore actually development in the most rational way. In history human consciousness is, according to Hegel, gradually developing, continuously going through the three successive dialectical stages of thesis, antithesis and synthesis, lintil at last, at the end of history, perfect human self-consciousness will have been reached. In Hegel's philosophy the eighteenth century idea of progress was revived, and his philosophy pointed the way to a new subjection of history to rationalist philosophy. This happened in the philosophical trends of positivism and Marxism, which originated towards the middle of the nineteenth century. Auguste Comte, (the father of positivism) John Stuart Mill, Herbert Spencer and their disciples wanted to write a new scientific history which included only positive facts, from which generalizations could be made and general laws could be found in the same way as was done in the natural sciences. What Spencer and other early positivist sociologists actually did was to select and classify facts according to general principles, eg that all things develop from the lower to the higher and from the less complicated to the more complicated. In this way the facts of history were only used to illustrate general laws that were already presupposed. ${ }^{12}$ )

It was realized by philosophers and historians of the later nineteenth century that the attempts of the positivists to 
write history according to the methods of natural science actually distorted history; with these methods the real nature of history could not be grasped. History should therefore be studied with other methods than those of the natural sciences. H. Rickert introduced the concept that there were two kinds of sciences, natural sciences, which were directed at the study of general laws, and historical sciences or humanities, directed at the study of individual, unique phenomena. The methods of the historical sciences should therefore be methods suitable for studying the unique, and the methods that had been developed by nineteenth century historians were seen as the best methods for these sciences. History was considered to be the basic humanity, with other disciplines, the so-called social sciences, as auxiliary disciplines to aid history in its study of unique events. In this view history was regarded with respect, with reverence even, and the idea of historism emerged. It came to be believed that from history human society human life and man himself could best be known. Culture, science, art, morals, etc., were thoroughly influenced by history; actually it was believed that science, art, etc as such did not exist, because every period of history has its own conception of science, art and morals. There are no general laws which are valid for the science, arts and morals of all ages, and all human activities are relative to the process of historical development, which is the only remaining absolute. In the view of historism history is not subjected to general laws of nature or reason as was done by eighteenth and nineteenth century rationalists, but, as in the Romantic view, history itself is a law. While Romantics regarded specific historical developments and traditions as norms which should be obeyed, the historist view assumes the process of historical development to be a law which absolutely determines life and society at any place and time. ${ }^{13}$ )

In the Romantic and historist views the value of history was so apparent that historians themselves were not confronted by this problem. In the era of the Romantics it was generally accepted that a study of history was 
necessary to learn the traditions which should be followed, and there was a general interest in the works of historians of that time. According to historism history could provide a solution to all riddles of human existence and all historical study was therefore important. The historians of the Romantic period tried to write national histories, showing lines of development and depicting the atmosphere of past ages and used original documents, for the study of which sophisticated methods were developed. With the rise of universities as centres of scientific research during the nineteenth century, it became possible for those interested in historical study to become professional historians and devote their lives to the careful and scientific study of some period of history. The rationalist idea that scientific research was an end in itself prevailed at these universities, and when historism emerged with its view that history was all-important and the study of it was an end in itself, this served to confirm the view of the professional historians that history should be studied for its own sake. It became fashionable among historians to study only subjects in which original documents and the well-established methods of dealing with these documents could be used. Historians were especially trained in the study of original documents, and only by means of works based on documents could one establish the reputation of being a good historian. The study of larger periods of history, based on the works of other historians, was not regarded as very important, and few historians devoted much of their time to works of historical synthesis.

When the views of Romanticism and and historism were prevalent the value of the historian's work was not seriously questioned. During the twentieth century, however, new philosophies emerged which influenced the general view of history. Existentialism, which was to a large extent a continuation and offshoot of historist thinking, regarded true history or Geschichtlichkeit as only consisting of the moments of free existence which can be achieved by escaping from the surroundings, including the past, to which all human beings are tied. The history which was studied by professional historians was not regarded as of much importance by 
existentialists. It was believed that the historical disciplines, as the other sciences, served to strengthen man's enslavement. ${ }^{14}$ )

During the twentieth century a new form of positivism developed which strongly influenced the outlook and thinking of scientists in most disciplines. Twentieth century positivism, as the original positivism of Comte, regards the finding of general laws to be the real business of science. In the positivist view history is mainly useful to provide facts from which generalizations can be made by social scienctists. Philosophers who belong to this movement are trying to point out that historians' explanations of individual events presuppose general laws, that historical events are therefore determined by laws, and that knowledge of these laws will lead to a clearer understanding of history than is possible by using traditional historical methods. ${ }^{15}$ ) The discipline of history, with its established methods, was not able to adapt itself easily to these changes in the general view of history. During the nineteenth century, when the Romantic and historist views prevailed, the value of their work was taken for granted, but now it is seriously questioned. Although the Annales-school in France and a number of movements in the United States have tried to bring a reorientation in the discipline of history, ${ }^{16}$ ) many historians are clinging to the old view that history should be studied for its own sake and are producing works in the old tradition. General views held formerly on the value of history and the task of the historian have shaped the historical discipline in such a manner, that it now faces a crisis.

From this brief survey of the different views pertaining to the value of history that were prevalent in past centuries it emerges that history was not considered as very important before the nineteenth century. It was regarded as good for moral education and for entertainment, but it was certainly not seen as of equal importance as the study of the natural sciences. In the ninteenth century, however, history was seen as something all-important which laid down norms for conduct in the present and determined all human 
activities. While the importance of history was first undervalued, it was now overvalued, and at no time was the value of history seen in its true perspective.

\section{WHAT SHOULD BE THE AIMS OF HISTORICAL STUDY? \\ The views of history of the Ancient Greeks, eighteenth} century Europeans, Romantics, historists and positivists all form part of more comprehensive views, encompassing the whole of reality, that were held by these people. In the general philosophy that was prevalent from the seventeenth century onwards some part of reality was regarded as absolute: human reason (with the implications that reason has unlimited possibilities, that mankind is able to reach a state of perfection, and that history shows man's progress towards perfection) or history, as was the case with historism. In a Christian view of reality neither history nor reason nor any other part of reality can be regarded as absolute, because the whole of reality is seen in relation to God. No human activity can be considered to have an end in itself, because in all his activities man's aim should be to serve God and fulfill the task for which God has called him. When service to mankind or man himself is made the ultimate aim, some part of reality is considered absolute and everything else seen in relation to it, this leads to a distorted perspective on reality. In a Christian view history cannot be regarded as absolute nor as something subordinate or relative to any other part of reality, and this view therefore opens the way for a true perspective on the value of history and of historical knowledge for human life and society.

In carrying out a task one has to combine different kinds of activities; building a house, for instance, does not only involve laying bricks, but also calculating, designing, buying materials, organizing people. Scientific study contributes to the fulfilling of many different tasks, and it does not always make the most important contribution. Scientific study should be done in harmony with other activities in order to ensure that man's work in the service of God is carried out well. Science should not be seen as something to be pursued for its own sake, thereby 
isolating it from other activities, nor as something which is only important for its practical use, thereby making it subservient to other human activities, but as one of a number of human activities which are all and together necessary for fulfilling man's work in general. Only in this perspective can science be seen in relation to the rest of human life, can it be truly relevant science. In order to do relevant scientific study the scientist should not be isolated from the problems of his society, towards the solution of which he must contribute, but live a full life within his society. This also means that scientists must, so far as possible, work independently and that their work must not be made subservient to certain political, economical or other interests, which would prevent science from fulfilling its role in society fully and properly. ${ }^{17}$ )

History is one of many sciences which all study some aspect of reality and of human life, culture and society. From a viewpoint in which no part of reality is absolutized it cannot be regarded as exalted above other desciplines nor as subordinate to other sciences. Together with all other sciences it should contribute to the carrying out of man's task on earth and must be relevant for practical life.

The traditional view that past events should be studied to serve as examples for human conduct in the present, does not make history a truly relevant science; actually this view prevented history from being studied scientifically in the past. During the nineteenth century it was realized that every event can only be properly understood within its context, because it forms part of a larger coherence of events. An event, taken out of its context, cannot serve as an example for another event which is happening within a quite different context. Athenian democracy cannot be used as a model for present-day democracy because it functioned within circumstances quite different from those of today. This does not mean that we cannot learn anything from Athenian democracy; studying this particular instance of democratic government helps us to understand democracy itself more clearly, and this 
general view of democracy, in turn, can help us to understand problems of contemporary democratic governments. One event cannot directly serve as a rule for another event; it can only be used to form a general rule which is applicable to other events. ${ }^{18}$ )

During the nineteenth century the true nature and significance of history was better realized by historians and philosophers than in the centuries before, but the erroneous view that the concrete events of history themselves can serve as a rule or norm for the present, remained. In the age of the Romantics historical tradition was regarded as a norm, because it was seen as the best way in which things - under the guidance of God, - could have developed. It was believed that one should therefore not try to alter the course in which things are developing, but only follow this course. In this way history showed what ought to be done. It was not realized that historical developments cannot have normative value because they are themselves subject to norms or laws. It is essential to a Christian life and world view that man is sinful; therefore he does not act always and everywhere as he should. And as historical development is the result of the work of sinful men, therefore it cannot always be the best way in which things could have developed. There is good and evil in history; there is divine guidance but also the influence of Satan in history. In a Biblical view the work of Satan in history forms ultimately part of the divine plan, but this does not relieve Christians from their responsibility of reforming and purifying what is wrong. 19)

Because all men are sinful and no human being is infallible, no actions of any historical person and no tradition can serve as a rule for conduct in the present. It is necessary to examine all traditions critically, in the light of the Word of God, and it may sometimes be necessary to break with traditions of centuries, as was for instance done by the Protestant Reformers of the sixteenth century. History cannot provide principles for life and society in the same way as the Bible does; only a critical study of history, and of all other aspects or reality, can lead to the finding of principles for human life. 
The Romantic view that it is impossible to alter the course of history, e $g$ as was attempted by the French Revolution, is also incorrect. Had the Romantics lived a century later they would have realized that the French Revolution had an enormous impact on Western Civilization and certainly influenced the course of history. In 1815 an attempt was made to restore the prerevolutionary order, but it failed ultimately. This does not mean that the French revolutionaries succeeded in totally reorganizing society according to the principles of pure reason as they had hoped to do; some of the radical changes they made, as for instance the introduction of a new religion of reason and of a new calendar, did not last. The French Revolution brought about enormous changes, but there was no total break with the past. There is always change and continuity in history; in some ages there is much continuity and little change, then sometimes there are far-reaching changes, like those caused by the Protestant Reformation and the French Revolution. There is always change in continuity; it is never possible to break totally with the past or to prevent all change.

A study of history therefore brings insight into the relation between continuity and change in history in general and in certain ages. One cannot learn from history whether a certain tradition should be changed or not, but one can learn what the strength of a tradition is, in how far it is ingrained in a society, and therefore what the consequences of a change are likely to be. History can help to show the best way in which a certain change can be carried through. It is the political scientist, and not the historian, who can point out, on the basis of his knowledge of political systems, what the defects of a particular system are and which changes are desirable. But it is the historian, and not the political scientist, who is able to explain the causes of the defects, to see the economic, social and other factors which led to them, and it is also the historian who is best equipped to foresee the consequences of changes for economic and social life, for culture and society in general. In his study of historical developments the historian has to deal mostly with all 
the aspects of human culture in their relation with one another, and he is therefore able to foresee some of the consequences which actions taken in one field (e g politics) will have for other fields and for society in general.

Knowledge of history provides historical perspective, which gives an extra dimension to our perspective on the society we live in. Without this dimension the institutions, customs, ideas and events of the present would be experienced as static or (especially in the case of events) as totally fluctuating. History gives perspective on the way in which the things we experience today have originated and developed and also on when and why, and this gives some idea of how they are likely to develop further on in the future. One can learn the direction and, to some extent, the tempo of development of the institutions, customs, etc, of present society. This does not mean that history shows the direction into which things inevitably have to develop; it shows the probable direction when no determined effort is made to alter the course of development. Historical perspective is therefore necessary to decide whether a trend of development is (from a certain point of view) desirable or not and whether it is necessary to work for bringing an alteration to this course.

The development of history, which is the development of cultures and societies in time, is effected by the people living in these societies, and in order to change the course of development in a situation it is often necessary to influence the beliefs, customs and/or actions of large numbers of people. This does not mean that it is impossible to influence the course of development decisively, as was believed by the Romantics, but that only people who have power in a society - whether political, econonic or intellectual power - have the means to work purposely for bringing about important changes. Actually all people have some power, even if only over their own children, and historical perspective aids them in showing them how they should use this power, what responsibility this power gives them. An historical sense forms part of a sense of responsibility and of a 
perspective on the task which one has to fulfill in the situation in which one is placed.

Historical perspective therefore influences our whole outlook on our time and society, our whole way of life, also the way in which we plan and organize our lives. The less historical perspective one has, the more one will be inclined to let one's actions be determined by the events of the day, to drift along with the course things are taking; the more historical perspective one has the more one will be inclined to determine and plan the course of one's actions oneself and to work towards the achievement of set aims. Historical perspective therefore does not bind one to the past and to tradition, but actually helps to free one from the bonds of tradition: "it helps to break to the cake of custom and prevents the crystallization of the status quo". ${ }^{20}$ ) When there is a general lack of historical perspective in a society the society can have little influence on the course of its own development. This may lead to the formation of a traditionalist society, as is the case with most primitive societies, or of an "establishment" of which the course of development cannot be controlled and from which there is no way out, as seems to be the pattern our own society is taking.

It is evident that every human being has some historical perspective. Everyone experiences in the course of his life that things are changing, and when he has some idea of his own life-history and that of the community in which he is living he must have some historical sense. Real historical consciousness, which gives perspective on one's place, task and responsibility in one's own community, however, should include perspective on the development of the society of which this community forms part, and also on the history of the world in which this society exists. To gain historical perspective on for instance the role of a church in a certain community, not only the development of churches with in the country but the development of the whole Christian Church, from its origin, gives the necessary background; the larger the scope of history in which a present phenomenon is viewed, the wider and deeper is the perspective which is gained on it. World historical perspective is only possible 
through historical study. An extensive study of history as such does not ensure such perspective; it depends on the way in which history is studied, whether not only factual knowledge but also an understanding of history is obtained through this study.

It appears from the above that historical perspective is intimately related to a view of the nature of history. The view of the Ancient Greeks did not permit the forming of real his torical perspective: A linear view of history and a sense of the unity of world history is a prerequisite for getting perspective on world history. In the view of the Romantics too much weight was given to historical tradition; this made a true perspective impossible. Only in a Christian view of history the nature of history and its relation to the rest of reality is seen in such a way that historical perspective, such as is described in the above pages, and an idea of the value of history is really possible.

The Christian view that world history takes its course under the guidance of God does not mean that it is possible to perceive direct interference of God in specific events. Scientific knowledge can only give a limited understanding of reality and it can not explain a certain event which happened at a certain time and in a certain way. God works in history through people, who are acting in accordance with their responsibility in every situation or not in accordance with their responsibility, that is, as they ought to or ought not to. Divine guidance of history therefore does not eliminate human responsibility and freedom. ${ }^{21}$ ) A Christian view of history actually puts this responsibility in perspective. True historical perspective on one's own society and situation makes it possible to form an idea of the direction in which one should work and of the responsibility one has of fulfilling a task within this situation.

Historical perspective is of the utmost importance for directing all kinds of human actities, and it influences human life in its totality. The study of history is therefore 
certainly as important as the study of economics or physics or of any other discipline. Only a study of history which leads to the formation and enhancing of historical perspective is really valuable and relevant to life and society today. There are, of course, other services which historians are able to render; they may, for instance provide historical knowledge which is needed in other sciences. Study of history at school can also lead to moral education, and to a more intimate undertanding of human nature. These things should, however, be seen as sideresults of the study of history which follow automatically from studying history with the aim of obtaining and deepening historical perspective. ${ }^{22}$ )

\section{CONCLUSION - WRITING RELEVANT HISTORY}

What does it imply to write history with the aim of gaining historical perspective on one's own time and society? Some consequences of this view of the task of the historian on the practice of history writing will be briefly pointed out.

The historian, as do other scientists, has to contribute to the understanding and solution of the problems of his own time. It is only the historian who can provide the necessary historical perspective on institutions, events and issues of his time, and this forms an essential part of his task. It is, for instance, the responsibility of contemporary South African historians to study the development of the relations between the different races and peoples in South Africa and to place present problems in this connection into historical perspective. The task of the South African historian does, however, not only include the study of South African history, but the study of all history that is of importance in understanding the origin and development of contemporary South African institutions, ideas, tendencies, customs, etc. Historians have to select subjects which bear upon present problems; should they fail to do so they would be evading their responsibility as historians who live and work in South Africa today, 
It is, however, not necessary for every subject of historical study to have a direct bearing upon present circumstances. Studies which directly refer to present problems are only possible when based on wider historical study. Works on the political institutions of the late Roman empire, Medieval France and seventeenth century England are important to obtain a view on the general development of political institutions in Western Civilization, and only against the background of this general development can recent developments in the South African political system be studied properly. The historian who wants to contribute towards the formation of historical perspective of his own fime and society must always keep the purpose of his study in mind. When studying the political institutions of the later Roman empire he should do this against the background of what is already known of the evolution of political institutions in the Western World. This will enable him to see which problems demand his special attention to make his work relevant to the study of the general development of political institutions. Furthermore, a subject should not be selected with the vague notion that it will be of some significance, without deciding first if it is important enough to devote a year or a decade or a life-time to it. Contemporary historians are responsible to ensure that those subjects which are most important today will not be neglected.

Historians should also give due attention to the writing of works of historical synthesis. As appears from the above most studies of special subjects are only important in so far they contribute towards knowledge of general developments (which is, in turn, necessary for gaining historical perspective on our own time); if the writing of histories of a more general nature is neglected, these special studies become meaningless. The erroneous view that the study of limited subjects which can be based on original documents is the real business of the historian, was responsible for neglect of the writing of general histories in the past. Today historians are more conscious of the importance of more general studies, although the idea still persits that historians should not 
devote too much of their time in writing such works. In order to carry out this vital part of the historian's task properly, it is, however, necessary that many historians should engaged only in writing works of historical synthesis which are based on studies of special subjects. Because it is the ultimate task of the historian to place present problems of his own society in historical perspective, historians of every age and country must write general histories which are especially suitable for their own society. Historical studies about countries and ages which are remote from one's own may be of importance, but they must be made relevant through works of historical synthesis.

Writing history which is relevant for today does certainly not imply to rewrite history from a contemporary viewpoint. It is the task of the historian to put his own time and society in the perspective of history, and not to put history in the perspective of his own time. The historian's outlook is always influenced by the circumstances of his time, and historians cannot, should not avoid giving their own view on historical issues, for it is their task to interpret history. ${ }^{23}$ ) Still the historian has to try to study the past as objectively as possible, thereby putting his own time and society in an historical perspective which is as true and correct as possible. As discussed in previous sections the outlook of the historian, his life-and-world view, which includes his view of history, determines his idea of the aims he has to achieve and of how he should do his work to achieve them. In order to give true historical perspective on present problems and to write relevant and objective history the historian should not merely adopt the dominant view of his time. Only a Christian view of history clearly shows the aims the historian has to achieve, which are the first requisite for knowing what the historian should study and in what way, and thereby provides an answer to the present crisis in historical study.

P de KLERK

PU for CHE 
1) On the present crisis in historical study see: $O$ Anderle, Theoretische Geschichte. Historische Zeitschrift vol 185 pp 1-54; F Wagner, Moderne Geschichschreibung. Berlin, Duncker \& Humboldt 1960; P de Klerk, Geskiedenisvergelyking. Die gebruik van vergelykende metodes wat gerig is op generalisasie in die geskiedkunde. Potchefstroom, Pro Rege 1973 pp 48-52; M Ballard (ed), New movements in the study and teaching of history. London, Temple Smith 1970.

2) For discussions of these new methods see: $W$ Aydelotte, Quantitative history. Reading, (Mass.), Addison-Wesley 1971; A G Bogue, U S A: the "New" political history. Journal of Contemporary history vol 3 no 1, Jan 1968 pp 5-28; Anderle, op cit.

3) Thucydides, The Peloponnesian war. Penguin Books 1968 (transl) p 124.

4) Cf F Wagner, Geschichtswissenschaft. Munchen, Freiburg 1951 p 11; W den Boer, F W N Hugenholtz and $\mathrm{T}$ J G Locher, Gestalten der geschiedenis in de Oudheid, Middeleeuwen en Nieuwe Tijd. Den Haag, Bakker 1960 pp 10,45,56.

5) Cf G H Nadel (ed), Studies in the philosophy of history. New York, Harper \& Row 1965 p 51; J T Shotwell, The history of history. New York, Columbia University Press 1939 p 234.

6) This term is used by Nadel in his above-mentioned work.

7) Cf Den Boer, Hugenholtz and Locher, op cit p 129; H E Barnes, A history of historical writing. New York, Dover 1963 (second edition) pp 60, 86.

8) J Bodin, Method for the easy comprehension of history. New York, Octagon 1966 (transl) pp 9,435. 
9) In the words of the philosopher David Hume. Citation in C H Jarvis, The teaching of history. Oxford, Clarendon 1917 p 7.

10) Cf E Fueter, Geschichte der neueren Historiographie. Munchen, Oldenbourg $1911 \mathrm{pp}$ 415-416; J W Thompson and B J Holm, A history of historical writing. New York, Macmillan 1954 vol 1 p 134.

11) For Groen van Prinksterer's view see his work Ongeloof en revolutie; eene reeks van historische voorlezingen. Amsterdam, Bottenburg 1904 (third edition).

12) For further discussion see De Klerk, op cit pp 34-37. Cf also Wagner, Geschichtschreibung, p 332; Fueter, op cit $\mathrm{p} 584$.

13) Cf Wagner, op cit p 33; De Klerk, op cit pp 39-40.

14) Cf W Bruning, Geschichtsphilosophie der Gegenwart. Stuttgart, Klett 1961 p 208.

15) For further discussion of this view see $S$ Hook (ed) Philosophy and history, A symposium. New York, University Press 1963; P Gardiner (ed), Theories of history, New York, Free Press 1959; M Mandelbaum, Historical explanation; the problem of "covering laws". History and theory, vol 1, 1961 pp 229-242.

16) About these movements see: Barnes, op cit pp 291406; Wagner, Moderne Geschichtschreibung.

17) Cf J A L Taljaard, Teorie en praktyk. Perspektief (Potchefstroom) vol 1 no 3 1962; N T van der Merwe, Enkele gedagtes oor wetenskap vanuit 'n wysgerige gesigspunt. Perspektief vol 2 no 2 \& 3, 1971; H G Stoker, Beginsels en metodes in die wetenskap. Potchefstroom, Pro Rege 1961 pp 133-150.

18) About this fallacy of reasoning from analogy see $D$ H Fischer, Historians' fallacies, Toward a logic of 
historical thought. New York, Harper \& Row 1970 pp 243-262; De Klerk, op cit pp 87-94.

19) Cf K J Popma, Calvinistische geschiedenisbeschouwing. Franeker, Wever 1945.

20) P J Fay, Objctives of history teaching in the university. Education vol 50 no 7 pp 391-392. Cf Fischer, op cit p 316; L Gottschalk, Understanding history. A primer of historical method. New York, Knopf p 269.

21) For a discussion of this problem see M C Smit. The divine mystery in history. Free University Quarterly vol 5 no 2 March 1958.

22) Cf L F Jackson, A single aim in history teaching. The history teacher's magazine, Oct 1914 p 248.

23) About the problem of historical objectivity see D W Kruger, Die relatiwiteit van die geskiedbeskouing, Koers vol 13 1945-46; W Bauer, Einfuhrung in das Studium der Geschichte, Frankfurt, Minerva 1928 (reprint 1961) pp 85-90; G J Renier, History. Its purpose and method. London, Allen \& Unwin 1950 pp 249-251. 


\section{AIMS AND METHODS OF HISTORICAL COMPARISON}

\section{INTRODUCTION}

Historical comparison is gaining interest with an ever larger group of historians. This probably results from various motives and interests. Some historians want to make history more relevant to the present and want to elucidate contemporary problems by means of historical study. This aim may possibly be achieved by comparing similar situations and events of former and present times. A comparative study of civilizations (for which Toynbee has set an example) may for instance point out the prospects of Western Civilization and thus throw light on the future. Others want to use comparative methods to arrive at historical synthesis. In recent times there has been an urge for universal history, emerging from a strong sense of the unity of mankind, and historians are trying to write the history of the common experiences of the whole human race. The limitations of the traditional purely national approach could be overcome by means of historical comparison; "the comparative method is the surest means of diminishing racial, political, religious and national prejudices"') Another motive for using comparative methods is to do historical interpretation without having to study the masses of documents which are available on subjects of the nineteenth and twentieth century period. ${ }^{2}$ )

Although some articles have been written lately on historical comparison, ${ }^{3}$ ) there is still much confusion about the possibilities and limitations of comparative methods, and nobody has, to my knowledge, tried to outline the correct procedure for using these methods. "Von einer Technik der Vergleichen bleiben wir weit entfernt. Sie treten, gerade heute, massenhaft auf, aber planlos und ohne Zusammenhang; und wenn sie einmal in einem tiefen, noch festzustellendem Sinne treffend sind, so verdankt man es dem Glück, seltener dem Instinkt, nie einem Prinzip. Noch niemand hat daran gedacht, hier eine Methode auszubilden."4) I want to point out that, in order to form more definite knowledge about 
the uses and possibilities of comparative methods, the different kinds of historical comparison must first be clearly distinguished from one another, and I shall attempt to show that there are a number of basically different methods of comparison. Only methods of historical comparison are discussed, $i$ e all kinds of comparison used by historians in historical study.

Comparison itself always involves the same procedure of finding differences and resemblances between two or more entities. It is impossible to compare by looking at resemblances only or by merely studying differences, for only by taking into account both differences and resemblances is it possible to see in how far two things are similar to, or different from each other. But, although comparison itself always implies the same procedure, a comparison can be directed at a special purpose and a comparative method can be formed to achieve the aim of the comparison. For instance, a comparison can be directed at ascertaining the amount and nature of differences between a number of similar entities, in this way distinguishing them more clearly from one another; this we shall call comparison for individualization. Comparisons can also be directed at finding certain kinds or correspondences or relationships between a number of entities, and, according to the kind of relationship looked for, comparisons with the respective aims of synthetization, generalization and reconstruction can be distinguished. In addition one should distinguish the historical analogy from these kinds of comparison. ${ }^{5}$ ) The different methods of comparison are not mutually exclusive, although some scholars favour only one or two of them, depending on their particular views of history

\section{COMPARISON FOR INDIVIDUALIZATION}

There is a kind of comparison which is directed at ascertaining and pointing out what is peculiar, particular to a certain historical period, event or institution. This comparison is mostly done between entities which look very similar and of which the particularity of each is not apparent. Individualizing comparison can be 
used in order to show that something really is a separate entity with special properties, but one must already assume that it is a "something", a particular entity in order to be able to compare it with some other entity. Individualizing comparison is a method for distinguishing the properties, which are individual to a certain event, from those which it has in common with others.

There are examples of individualizing comparison in the works of ancient historians such as Polybius (201 - $120 \mathrm{~B}$ C). He compared the Roman empire with other empires of antiquity to point out in which way the Roman empire was different from and superior to them..$^{8}$ ) Only in the nineteenth century, however, much attention was given to this kind of comparison, and it became to be considered the ultimate purpose of historiography to describe historical periods and events as they really were. During the age of Romanticism historians for the first time really tried to penetrate into the inner life of past periods and people. According to the philosopher $F$ Schleiermacher this divinatory method should be supplemented by a method of comparative interpretation, in order that every event can be seen from a more general point of view and that its uniqueness can stand out better. Wilhelm Dilthey declared: "Divination und Vergleich sind in einem zeitlich Ununterschiedenen mit einander verbunden. Wir können ein komparatives Verfahren in Bezug auf das Individuelle niemals entbehren."7) In his work on historical methodology Ernst Bernheim considered the comparison directed at individualization a valuable device in the art of historical interpretation..$^{8}$ )

Today there are still many historians who believe that they should only be interested in what is unique in history, "precisely in what differentiates one thing, person, situation, age, pattern of experience, individual or collective, from one another" 9 ), and that all historical comparisons should therefore be directed at individualization. Others, who accentuate the need for historical synthesis or generalization, are mostly 
advocating synthetizing and generalizing comparisons and are not interested in individualizing comparison. Nevertheless, it is evident that one cannot synthetize or generalize without knowing the individual first. Individualizing comparison can be of use in any kind of historical study, not only to study the individual properties of a certain historical event, but also to study its causes and to find an explanation which fits the event in its particularity. Marc Bloch used the individualizing comparison to explain why Florence and Genua were the first municipalities in medieval Europe to issue gold coins. The explanation that the wealth of these cities was the cause of the early gold-coining was not sufficient, because Venice was at least as rich, but began goldcoining only three decades afterwards. By comparing the three medieval cities with one another he found that Genua and Florence had, unlike Venice, a favourable trade balance with the orient and were paid in gold for the cloth they exported. This was an explanation which accounted for the differences between Genua and Florence on the one and Venice on the other hand. ${ }^{10}$ )

Individualizing comparison as the ascertaining of differences should be an integral part of the process of historical interpretation itself. Usually it has only to be done to some extent and not very systematically and comprehensively, and a definite technique for doing this kind of comparison does not have to be formed; it forms part of the historical method itself. ${ }^{11}$ )

\section{COMPARISON FOR SYNTHETIZATION}

Whereas individualizing comparison is directed at differences, synthetizing comparison is aimed at finding similarities, but only similarities of a particular kind. The aim of the comparison is to make a synthesis of a number of different historical events, institutions or periods.

Synthetizing comparison has been done in some form or other since ancient times. When the expansion of the Hellenic Civilization over the Mediterranean world, during the fourth and third centuries B C, brought a new 
sense of unity among different peoples, historians tried to bring together the separate histories of the Greeks, Egy ptians Assyrians and Jews. Actually they only aimed at synchronising the different histories and they only made a chronological synthesis. The same kind of comparison was done during the fourth and fifth centuries A D, when the spread of Christianity brought with it a still larger sense of the unity of history. It was only when historiography achieved a more scientific standard, during the nineteenth century, that synthetizing comparison came to be done systematically. In a study such as Jacob Burckhardt's work on the civilization of the Renaissance in Italy, synthetizing comparison was done implicitly to form out of the many different episodes and scenes in the Italian cities of the Renaissance period a picture of the Italian Renaissance as a coherent whole. ${ }^{12}$ ) In our times the use of synthetizing comparisons is strongly advocated by historians such as $T$ Schieder and D Gerhard. Schieder sees in this kind of comparison the possibility to form so-called real types of individualities of a higher order. He describes the process to arrive at these real types as follows:

"Wir steigen von kleineren Einheiten zu immer grösseren auf. So denn wir zuerst uns eine Anschauung von einem deutschen Fürsten zum Beginn des 18. Jahrhunderts verschaffen, zum Beispiel von Kurfürst Max Emmanuel von Bayern. Dann kennen wir ein lokal begrenztes Bereich, eine besondere Persönlichkeit aus diesem Jahrhundert. Wir rücken dann zu nächsten grösseren Einheit vor, dem deutschen Fürsten im 18. Jahrhundert. Wir suchen bereits individuelle Zugen höheren Grades und fragen: Wie beispielsweise regierte der durchschnittliche Fürst dieser Zeit? Von hier aus kommen wir zu der Epochbestimmung des Absolutismus. Sie setzt sich aus vielen kleinen Mosaiksteinen zusammen, wobei wir uns aber stets an die konkrete Wirklichkeit zu halten, Charakterisches herauszuarbeiten versuchen. Wir steigen also zu grösseren Einheiten auf, indem wir kleinere zusammenfassen." ${ }^{13}$ ) 


\begin{abstract}
Although Schieder considers this procedure a coming from the individual to the general, it is actually a coming from a smaller to a larger whole (which is still individual); a different method, the generalizing comparison, should be used to come from the individual to the general.

Not all similarities between two or more different things are relationships which point to their belonging to a larger whole; some resemblances between events of utterly different periods (eg between the murder of Caesar and the murder of Lincoln) cannot be accounted for by their being part of some larger historical coherence. In order to find correspondences which can be used for synthetizing, only entities which are near to one another in time and place must be compared; for a larger coherence or whole is a coherence within a different time and place. The synthetizing comparison can be considered a synchronical comparison, as distinguished from the generalizing comparison, which has the character of a diachronical comparison. ${ }^{14}$ )
\end{abstract}

When one arrives at a larger whole by means of a synthetizing comparison, this does not mean that it embraces the compared entities in their totality, as Schieder seems to think. ${ }^{15}$ ) Prince Max Emmanuel of Bavaria can be considered a typical example of an absolutist ruler, but also (for instance) a typical example of a prince of the House of Wittelsbach. He has some characteristics which make him part of other coherences as that of rulers in the age of absolutism, and some characteristics which are individual, particular to him only. Every event which forms part of a larger whole can at the same time be itself a coherence of smaller events; the life and reign of prince Max Emmanuel consists of many episodes. History consists of numerous events which are coherent with one another in various respects. This means that in making an individualizing comparison one starts with some coherence or event which is already assumed to be individual, while in making a synthetizing comparison one has to direct one's attention from the outset at some individual coherence which is assumed to be a larger whole. Schieder must have had 
eighteenth century absolutism in mind as a larger coherence, in order to isolate only those characteristics in which smaller entities form part of this larger particular whole. The synthetizing comparison cannot give a criterion for deciding which larger coherence is of historical importance (and should therefore be the subject of a comparative study) and which is not.

When one calls a coherence arrived at by means of synthetizing comparison (eg eighteenth century European absolutism) a real type, one must keep in mind that it is only typical of a number of entities within a definite historical period and is therefore still an individual historical coherence.

Synthetizing comparison can be useful in all historical study. By using synthetizing and individualizing comparison together it can be ascertained what field a certain historical explanation should cover. Through individualizing comparison it can be seen when the explanation is not particular enough for some event, and through synthetizing comparison when it is too particular and does not cover the whole coherence of events. One cannot explain a typically European phenomenon only with causes that pertain to conditions in one or two European countries. The comparative approach to national history, by putting the experiences of the national country in broader perspective and comparing it with developments in foreign countries, enables the historian to see in what respects the history of his country is unique and in which aspects it forms part of larger historical developments. ${ }^{16}$ )

Synthetizing comparison should be done, like individualizing comparison, in all historical research and should form part of ordinary historiographical procedure. But it seems that it can also be done systematically, according to certain techniques, in order to synthetize, for instance, the histories of a number of nations and periods with the aim of studying the history of a civilization as a whole. This method can therefore be of assistance in writing the history of a civilization or 
historical period on the basis of a number of historical monographs on smaller subjects. As no techniques have as yet been designed for this kind of comparison further investigation seems necessary and should be very profitable for all historical study.

\section{ANALOGY}

Before turning to generalizing comparison we must first give some attention to analogy, which is sometimes confused with it and which should therefore be clearly distinguished.

The term "analogy" is often used in logic to indicate an identity of relation; four terms are called analogous when the first stands in the same relation to the second as the third to the fourth term. ${ }^{17}$ ) The word "analogy" is also used, in a broader sense, for any correspondence between some properties of two or more different entities. The historian Sidney Hook defines analogy as "a comparison which, on the basis of certain points of resemblance between two cases, suggests the existence of some further resemblance selected because of relevance to the purpose of comparison". ${ }^{18}$ ) When reasoning that, because a civilization grows and develops similar to a living organism, it must therefore also decline and disintegrate like an organic being, one is reasoning by analogy. ${ }^{19}$ ) Analogical reasoning therefore depends on the degree of resemblance between two or more entities. ${ }^{20}$ )

Historical analogies are often made. In classical times it was even considered the main purpose of historical study to supply analogies and examples. Contemporary events were compared with similar ones in history in order to learn what must be expected to happen and to avoid possible dangers. History had to teach lessons, supply examples, the value of which depended on their fitness to be applied to other situations; this is reasoning by analogy. This exemplar view of history was the generally accepted one for many centuries and lasted till almost the end of the eighteenth century. It has not quite disappeared even in the present. 
Can analogies be used to make historical knowledge applicable to the present? Is reasoning by analogy valid reasoning? Today most academicians agree that reasoning by analogy cannot be used as a means of demonstration but only to supply hypotheses, to point out possibilities. ${ }^{21}$ ) Therefore analogies can only show what may possibly happen; they cannot supply valid predictions. The nineteenth century historian Gustav Droysen pointed out that analogies can be useful in historical research, because "es sich um menschlichen Vorgänge handelt, die uns als solche durch gleichgeartes Wese verständlich sind"22) By comparing the personality of some historical person with that of someone known from ordinary life, this may lead to some hypotheses. Analogy is a means to find hypotheses but not a means to test them, and therefore it cannot be used as a scientific method according to particular techniques.

Some philosophers of history, among others Joseph Engel, claim that analogies are the only means of describing past events with concepts of our own time; "es gibt keine andere logische Möglichkeit einer Aussage über von uns verschiedenes Individuelles als die nach der Analogie". ${ }^{23}$ ) This overrating of the importance of analogy in historical study is unly possible in a view which denies real existence to the general besides the individual.

\section{COMPARISON FOR GENERALIZATION}

While reasoning by analogy implies the comparing of a number of resemblances between two cases, generalizing comparison consists of comparing a number of cases which need to have only two properties in common and is actually a reasoning by induction. ${ }^{24}$ ) While useful analogies are most often made without systematic study, generalizing comparison can only be done effectively through scientific and systematic research.

A generalizing comparison is a means of deducing a general statement from a number of specific entities. Actually a double comparison has to be done: first a number of units must be compared to ascertain that they 
have some property in common or belong to a common class, eg that all are cases of revolution. Then they must be compared again to find another similarity between them, eg that in all cases dictatorships emerged at the end. The two similarities can now be linked up to form a general statement: all revolutions lead to dictatorships. This statement is independent of the specific cases which were used and should be applicable in general, i e for all times and places. Usually this comparison is done with a general hypothesis already in mind, and it therefore is essentially a means to test hypotheses. The testing of an hypothesis through study of a number of cases should not be confused with the illustration of a general statement with a number of examples. This form of comparison, if it can be named a comparison at all, is not a generalizing but an illustrating or paradigmatic comparison, as Schieder calls it. ${ }^{25}$ )

It appears from the above that it is impossible to investigate all cases to which a general statement should be applicable, as they can be of past, present and future and are theoretically indefinite in number. Therefore it is essential for generalizing comparison that a selection of cases for comparative study is made. This should not be an arbitrary selection, but one which includes as many differences between the cases as possible to ensure that resemblances are found which pertain to all and not merely certain cases of the class. The validity of the generalization is therefore not dependent on the number of cases studied but on their representativeness of the group studied. Generalization from only one case should be possible if that particular case is representative of the class in every aspect. This kind of generalization is often made in the natural sciences, but it cannot be done in historical investigation. By studying American democracy only, it is almost impossible to know what features are peculiar to the American case and what features belong to democracy as such. It is, however, not necessary to compare large numbers of democracies with the aid of a computer, in order to form generalizations about democracy; a study of, say, eight well selected cases should be sufficient. 
While generalizing comparison is directed at similarities and not at differences, it is not directed at all kinds of similarities. It is not directed at similarities which point to a larger whole like the synth etizing comparison, but at those similarities which point to a general law or rule. In order to eliminate similarities of coherence, cases should be selected which are removed from one another in time and place. Whereas synthetizing comparison is a synchronical comparison, generalizing comparison is essentially a diachronical one. By taking cases from different historical periods and, if possible, from different historical civilizations (because a civilization also is a coherence in history), it is furthermore ensured that they represent many variations among cases from the same class.

Comparison with the aim of finding something general in history, has like other forms of comparison, been done since ancient times. Already Hesiodos (8th century BC) compared different historical periods with one another, in order to form a general theory of history. Comparisons of stateforms and of their succeeding one another in history were done by scholars such as Aristotle, Machiavelli and Montesquieu. During the sixteenth century Jean Bodin wanted to compare and systematize the "examples" of history in order to form general knowledge of human morals. The exemplar view of history was, however, so commonly accepted that nobody thought it possible to form general knowledge only from historical study; history could only illustrate these statements, it was thought, and therefore paradigmatic instead of generalizing comparison was really done. This view even persisted during the nineteenth century when Comte, Mill and Spencer believed that general statements about the development of human society should be deducted from the laws of human nature and could only be corroborated by means of historical study ${ }^{26}$ ) One of the first scholars who postulated that general statements can be formed from historical knowledge alone was Giambattista Vico (1668 - 1744) who wanted to establish a general science of man, which should be at the same time an ideal, eternal history, by 
comparing different civilizations and peoples. During the nineteenth century Hegel, Marx, Von Lasaulx and Danilevski also made some comparisons in forming their theories of history; their procedures however, were not entirely inductive and systematical. It is only in the twentieth century that systematic comparative study, directed at historical generalization, has been done, although not yet according to definite and uniform techniques. Toynbee's study of civilizations is a wellknown example, but there are other, more methodical comparative studies, eg those of Robert Kann and Elias Tuma, on restoration and agrarian reform respectively. ${ }^{27}$ )

Is it to be considered the task of historians to make generalizing comparisons, or should this be done by social scientists only? The task of the historian cannot be limited to studying individual events; individual things cannot be known properly without some knowledge of the general. This does not mean that the historian should compare any kind of phenomenon that can be found in history in order to form generalizations; then history would become an all-encompassing study of human activities. The political scientists should compare political phenomena that can be found in history in order to form generalizations about politics and about the state, and the historian should compare historical phenomena in order to form generalizations about history. Generalizing comparisons of phenomena, such as the forming and development of civilizations, revolutions, restorations or the order in which stateforms succeed one another in history, should throw more light on the nature of historical processes as such and should lead to a better understanding of the nature of history. ${ }^{28}$ )

In developing a method of comparison for historical generalization much can be learned from the techniques of comparison which are used by social scientists. The method of concommittant variations, which was first postulated by Emile Durkheim, is much used in contemporary social science, especially in the form of largescale statistical comparisons, such as the cross-cultural 
and cross-policy surveys. ${ }^{29}$ ) The method of statistical comparison has the same underlying principle as described in the above: cases of the same class which are very different from one another are compared in order to find possible similarities between them. Durkheim called this the method of resemblance as distinguished from the method of difference, which is aIso a method of concommittant variations. The method of difference requires that a number of very similar cases, having one difference in common, are compared with the aim of finding some other common difference. The procedure is very similar to that of the individualizing comparison. The example cited above as a case of individualizing comparison ${ }^{30}$ ) can also be considered a case of generalizing comparison by means of the method of difference. According to Sewell Bloch,s comparison of the medieval city-states of Florence, Genua and Venice, which were similar in most respects and differed in the one respect that only the first two cities coined gold, led to the finding of another difference, $i$ e that only Venice and Genua had a favourable trade balance with the orient. Bloch,s procedure therefore led to the forming of a generalization: a favourable trade balance (with the orient) causes gold coining. According to this reasoning almost every individualization could be turned into a generalization. Sewell,s theory is in agreement with the Hempel-Popper-thesis according to which all historical explanation implies the existence of universal laws. Whether this thesis is accepted or not, it is evident that there is not much sense in forming all possible kinds of generalizations as there can be found as many general laws as individual events. Generalizations can be formulated in such a manner that, although they have general validity, only one (or no) event can be found in history to which they are applicable. Generalizing comparison should therefore rather be done by the method of correspondence, as this is a surer way of finding and testing generalizations which are important to the understanding of history.

From the above some features of the procedure which should be followed in doing generalizing comparison 
have already become apparent. The main elements of the procedure can be summed up as follows: ${ }^{31}$ )

a. Aim. The main purpose of a generalizing comparison should be to arrive at historical generalization. The historian may be interested to get perspective on some present day problems or future developments, but this can only be done as a result of the comparison, after generalizations have been formed, and not directly by means of the comparison.

b. Definition. The cases which have to be compared should belong to the same class or have one feature in common. This class or common feature must be clearly defined, in order to avoid circular reasoning by arriving at conclusions which were already implied at the outset. A definition is necessary to ascertain what the conclusions will apply to exactly and to state definitely whether certain cases belong to the class or not. The definition may be used as a means to limit the subject in order to make it a convenient field of study. When, for instance, it appears that there are too many cases that fall within the definition of revolution, the definition can be modified so that it refers to a certain kind of revolution only. The generalization will then only apply to this particular kind of revolution.

c. Selection of cases. As already stated, cases must be selected in such a way that they represent as definitely as possible the differences among the cases and that the influence of common features which point to similarities of coherence are eliminated. In order to make a representative selection a first elementary study of all the cases is necessary. The availability of material on the cases and the investigator's field of knowledge should also be taken into consideration when making the selection. The number of cases is not in itself a primary factor, but it is clear that the more cases selected, the better will all possible variations be represented. From recent comparative studies it appears that only a limited number of cases which are suitable for comparative study can be found about subjects such as agrarian 
reform and restoration, and that a selection of ten or twelve cases will be quite sufficient.

d. Method of research and presentation. The best procedure for comparative study of history seems to be the intensive investigation of a small number of cases in the context of their periods. This is to be preferred to the quantitative study of a large number of cases in a few (quantifiable) aspects which can only lead to certain kinds of generalizations and cannot supply very definite information. It is almost impossible to make a thorough study of original documents in a comparative study, as this should make it a life-work, but an intensive study should be made of all authoritative secondary works on every case. During the research process the investigator will form, test and revise hypotheses. The study of the separate cases and the comparison should form one single process; the investigator must continually pass from the one case to the other, every time looking at new aspects, until a theory is formed which is sustained and corroborated by all the cases. Therefore a comparative study can hardly be effectively done by a team of researchers, each of which studies one or two cases and one of them making comparisons.

The research process should be distinguished from the work connected with the presentation of the project in a publication. It is impossible (and unnecessary) to describe the whole research process and every case in detail. The best way of presentation seems to be to state a few hypotheses beforehand and then to deal with every case in relation to the hypotheses stated and on the basis of background description. Care must be taken that the hy potheses are tested and corroborated, and not merely illustrated, in every single case. This procedure is to be preferred to a thematological approach in which the main part of the work consists of the description of theories formed, every time referring to aspects of the different cases. This method does not allow the reader to judge whether every case as a whole fits the theory or not. 


\section{COMPARISON FOR RECONSTRUCTION}

The comparison that has been used most often by past historians is not one of those discussed in the above, but a comparison aimed at historical reconstruction. Parts of history on which information is scant are compared with parts on which more information is available in order to make a better reconstruction of the lesser known parts. Two different methods of reconstructing comparison can be distinguished; the first consists of the reconstruction of a part of a larger historical coherence, and is therefore connected with synthetizing comparison, and the second consists of reconstructing according to a general law, and is related to generalizing comparison. The first method was formed in the early nineteenth century during the Romanticist movement. The method was taken over from biology, where biological species were compared with one another to find resemblances which revealed relationships. Scholars such as Friedrich Schlegel and Franz Bopp compared a number of languages and found similarities between languages such as German, Greek and Sanskrit, which showed them to be members of one family of languages. It was deduced that these languages must have developed from a common original Indo-European language, and by means of the comparison they were able to reconstruct some elements of this pre-historic language. The successes of comparative grammar and comparative philology induced other scholars to compare myths, legends, customs, laws and stateforms of different nations in order to find correspondences of kinship and traces of a common origin. These comparative studies were, however, not quite as successful as the comparative study of languages, partially because too many similarities were found which could not have been caused by a common origin and therefore, perhaps, referred to general laws. ${ }^{32}$ )

The comparative method of Romanticism can best be seen as an application of synthetizing comparison: through comparison similarities of coherence are found from which deductions about unknown parts of the coherence are made. Because German, Greek and 
Sanskrit are linguistically and historically connected and form part of the same coherence, namely the family of Indo-European languages, some features of an unknown part of the coherence, namely the original Indo-European language, can be deduced. This kind of comparison is actually done in all historical research and interpretation. As Droysen already pointed out, ${ }^{33}$ ) historical documents are often inadequate to give a complete picture of some past event, but in the process of interpretation deductions are made on the basis of the known parts about the unknown parts of the event, and a coherent picture is formed. This comparison is a means to supplement the study of historical documents and not to replace it, although it might perhaps be possible to use this method in some way to by-pass the laborious study of less significant documents. In any case, the more this comparison is based on the study of historical sources, the stronger will be the validity of its results.

The reconstructing comparison on the basis of a general law is a very old method, and elements of it can be found in the works of the ancient Greeks. They found resemblances between the customs of primitive peoples and those of their own ancestors, and the idea originated among them to learn more about their own past by studying primitive peoples. ${ }^{34}$ ) Their comparisons were therefore based on the general assumption that all nations pass through a similar stage of primitive development. During the eighteenth century the idea of progress became generally accepted, and it was through that the nations of their own time represented various stages of human development. By comparing and putting together information about these peoples the whole history of mankind could be reconstructed as one process of gradual development from barbarism towards perfectability. Ideal, theoretical histories were written to replace the ordinary histories which were based on original documents and which contained many lacunes. The law of the gradual progress of mankind was taken to be a logical deduction from knowledge about human nature, and no attempt was made to test it through study of historical facts. ${ }^{35}$ ) Essentially the same kind of 
reconstructing comparison was done by early positivist scholars such as Comte, Mill and Spencer. Spencer tried to reconstruct the evolution of humanity by collecting many and different kinds of facts about various societies of past and present times and then arranged them in order from the lowest to the highest and from the most simple to the more complicated. This kind of procedure was also followed by some professional historians such as Karl Lamprecht and Kurt Breysig. Lamprecht tried to reconstruct German history within certain stages of psychological development and Breysig wrote a universal history on the basis of different stages of human development, in which he used some primitive peoples of contemporary times to describe the earliest stage.

This method of reconstructing comparison has received much criticism from historians. This criticism, however, was especially directed at the underlying assumption of human progress according to certain stages; writers such as Lamprecht and Breysig actually reconstructed history on the basis of their own philosophies. Furthermore some of these historians, and, especially, sociologists, did not base their work on a thorough study of historical facts, but instead they did their reconstructions by using all kinds of facts outside their context and without corroborating them through the procedure of historical criticism; they used comparative methods as a substitute for documental study. If more carefully done and only in case of lack of material, and if done on the basis of less controversial and empirically tested generalizations, reconstructing comparison could perhaps become a valuable aid to historical study. This kind of historical reconstruction should essentially consist of applying the results of generalizing comparison to individual cases on which documental information is not sufficient.

Reconstructing comparison should therefore not be considered a separate form of comparison, but should be seen as the application of the results of synthetizing and generalizing comparison to individual historical events. 


\section{CONCLUSION}

From this discussion of the different kinds of historical comparison it appears that each kind can be of considerable importance for historical study.

Individualizing and synthetizing comparison should play a large part in all historical research and interpretation, while analogies will al ways be helpful to form hypotheses of study. These comparisons should form an integral part of the historical method and need not be done very systematically; the activity of comparison is almost as important as the result in giving the historian more perspective on his subject. ${ }^{36}$ ) The historian must have a capacity for perceiving qualitative similarities and differences; the art of the historian should essentially be the art of comparison. ${ }^{37}$ ) Unfortunately too many historians still do not realize the importance of comparison in historical study. Synthetizing comparison should not be used in ordinary historical study only, but also in the special task of bringing greater synthesis in history, on the basis of historical works on smaller subjects. Although historians are today more conscious of the needfor historical synthesis than many of their predecessors were, there has not been done very much in this direction yet. One of the reasons for this unsatisfactory situation seems to be the lack of special methods and techniques for this kind of study; synthetizing comparison is most probably an important method for historians who are fulfilling this essential task.

Like synthetizing comparison, generalizing comparison can only be effectively done when enough special historical studies are available, and it is also essentially a method for the further interpretation of historical processes, and of history as such. The advancement of theoretical knowledge of history is of the utmost importance for all historical study, because, for instance, a specific revolution in history can be so much better studied when one has a clear idea of what a revolution really is. But, most important of all, this comparison can bring more perspective on the whole course of human history, and therefore on the present and on the future as well.

$P$ de Klerk PU for CHE 
1) C J H Hays, American frontier - frontier of what? American historical review vol 511946 p 215.

2) Cf T Schieder, Geschichte als Wissenschaft. München 1965, p 189 and F Redlich, Toward comparative historiography. Kyklos vol 111958 p 377.

3) Some of them are: A E Cohen, Vergelijken in de tijd. Groningen 1961; Gerhard, Alte und neue Welt in vergleichender Geschichtsbetrachtung. Göttingen 1962 pp 187 - 211; W H Sewell, Marc Bloch and the logic of comparative history. History and theory vol 61967 pp 208 - 218; F Wagner, Analogie als Methode geschichtlichen Verstehens. Studium generale vol 8 1955 pp 703 - 712; R Wittram, Das Interesse an der Geschichte. Göttingen 1958 pp 46 - 57.

4) Wagner, op cit p 707 .

5) I have taken over some of the descriptive terms which are used by Schieder in making a survey of different kinds of comparative methods. This does not mean however, that the methods which he distinguishes are in all respects similar to the methods I am discussing in this paper. Cf Schieder, op cit pp $187-211$

6) Polybius, Histories vol 1 Cambridge (Mass) 1960 (translation) p 5 .

7) W Dilthey, Gesammelte Schriften vol 7. Leipzig 1958 p 226.

8) E Bernheim, Lehrbuch der historischen Methode. Leipzig 1908 (first edition 1889) pp 606 - 607.

9) I Berlin, History and theory; the concept of scientific history. History and theory vol $11961 \mathrm{p} 18$.

10) This example is cited by Sewell, op cit

11) Cf Cohen op cit pp $19-20$.

12) J Burckhardt. Die Kultur der Renaissance in Italien. First edition 1860. 
13) Schieder, op cit p 45.

14) Cf Cohen, op cit.

15) Schieder, op cit p 201.

16) Cf C V Woodward (ed). The comparative approach to American history. New York, 1968.

17) Cf H W B Joseph, An introduction to logic. Oxford 1916 (first edition 1906) p 532.

18) Social Science Research Council, Theory and practice in historical study. New York 1946 p 108.

19) One must distinguish between using analogies to make deductions from them and using them only as metaphors in speech. When only speaking metaphorically about the growth or death of civilizations this has no logical implication.

20) Cf Bernheim, op cit p 611 and J S Mill, A system of logic. London $1843 \mathrm{p} 103$.

21) Cf Joseph, op cit p 540; Mill, op cit p 104; Social Science Research Council, op cit p 108; Bernheim, op cit $\mathrm{p} 129$.

22) J G Droysen, Historik. Vorlesungen über Enzyklopädie und Methodologie der Geschichte. München $1927 \mathrm{p} 146$.

23) J Engel, Aanalogie und Geschichte. Studium generale vol 91956 p 98.

24) Cf Bernheim op cit p 610 and $M R$ Cohen, and E Nagel, An introduction to logic and scientific method. London 1966 (first edition 1939) p 286.

25) Schieder, op cit $p 191$. 
26) Cf for instance Mill, op cit p 609.

27) R A Kann, The problem of restoration. A study in comparative political history. Berkeley 1968; E H Tuma, 26 centuries of agrarian reform: a comparative analysis. Berkeley 1965.

28) Cf Redlich, op cit.

29) See for instance $S$ Rokkan (ed), Comparative research across cultures and nations. Paris 1968.

30) See above.

31) In my work Geskiedenisvergelyking. Die gebruik van vergelykende metodes wat gerig is op generalisasie in die geskiedkunde (Historical comparison. The use of comparative methods which are directed at generalization in history). Potchefstroom, Pro Rege 1973, I have studied this procedure more elaborately and discussed a number of works in which generalizing comparison is done.

32) Cf E A Freeman, Comparative politics. London 1873.

33) Droysen, op cit p 163.

34) Cf Thucydides, The Peloponnesian war. Penguin Books 1968 (translation) p 16.

35) Cf K E Bock, The acceptance of histories. Berkeley $1956 \mathrm{pp} 64 \mathrm{ff}$.

36) Cf Cohen, op cit.

37) Berlin, op cit, History and theory vol 1 p 30 and Social Science Research Council, The social sciences in historical study. New York $1954 \mathrm{p} 151$. 